\title{
Path Dependence and Privatization Strategies in East Central Europe*
}

David Stark

\section{Introduction: Capitalism by Design?}

Across the ruins of Communism, a clear breeze blows from the West. Like the "fresh winds" that had been hailed from the East across the ruins of war more than four decades earlier, it promises prosperity through sacrifice. Like the old vision with its road maps to the promised land, this new vision comes with packaged formulas for applying economic science to the grand project of institutional reconstruction. In 1991 , no less than in 1948, devastation is seen as mandating boldness of action but also as presenting an opportunity: the collapse of the old order issues the imperative for ambitious experiments while offering the occasion to build anew, this time, with a fresh start to create capitalism by design.

As the juxtaposition of postwar Bolshevism and post-Cold War designer capitalism suggests, this paper is highly skeptical about analyses that approach the economic transition in East Central Europe as a problem to be solved by the rationalist design of economic institutions. Three sets of reasons inform this skepticism.

First, proposals for all-encompassing institutional change according to comprehensive blueprints suffer from an inadequate comparison of socialist and capitalist economic systems. ${ }^{1}$ Misled by the obviously superior efficiency and performance of capitalist institutions, such proposals mistakenly draw the conclusion that these institutions can be replicated according to instructions, whereas the deeper and more perti-

* Research for this paper was supported by grants from the National Science Foundation. My thanks to László Bruszt, Valerie Bunce, Janusz Dabrowski, István Gábor, Péter Gedeon, Peter Katzenstein, János Lukács, Gerald McDermott, Peter Murrell, Victor Nee, László Neumann, Andrzej Rychard, Jan Szomburg, Marton Tardos, Eva Voszka, and especially Monique Djokic Stark for helpful criticisms and suggestions at various stages of researching and writing this paper.

1. See, for example, Olivier Blanchard, Rudiger Dornbusch, Paul Krugman, Richard Layard, and Lawrence Summers, Reform in Eastern Europe (Cambridge, Mass., 1991). 
nent comparative lesson is that the failure of socialism rested precisely in the attempt to organize all economic processes according to a grand design. The notion that the more rational institutions can be implemented by conscious design thus duplicates the rationalist fallacy evidenced during the introduction of socialism with, for example, the Leninist notion that property relations could be changed overnight by administrative decree. Moreover, the premise that efficient institutions can be drafted at the systemic level ignores, as Peter Murrell acutely observes, the actual operations of existing capitalisms. ${ }^{2}$ The origins of capitalism in the West were not by blueprint, its development has not been directed by conscious design, and, as recent research in evolutionary economics and organizational ecology has demonstrated, its processes for selecting technologies and organizational forms are governed more by routine than by rational choice. ${ }^{3}$

The second reason to be skeptical about cookbook capitalism is that the systems designers and international advisory commissions who fly into the region with little knowledge of its history tend to approach the problem of "the transition" exclusively through the lenses of their own general models. Through such a gaze, differences among the countries in the region are merely differences in degree (the timing and rapidity of collapse, the strength of elite commitment to reform, the speed of introducing new policies, and the like). As a consequence, their analyses of developments in the region are the simple measurements of the degree to which a particular strategy conforms to or departs from a given therapist's prescriptions. Contrary to such views, we should instead regard East Central Europe as undergoing a plurality of transitions in a dual sense: across the region, we are seeing a multiplicity of distinctive strategies; within any given country, we find not one transition but many occurring in different domains-political, economic, and social-and the temporality of these processes are often asynchro-

2. Peter Murrell, "Conservative Political Philosophy and the Strategy of Economic Transition," in this volume.

3. See especially Michael T. Hannan and John H. Freeman, Organizational Ecology (Cambridge, Mass., 1989); Richard Nelson and Sidney Winter, An Evolutionary Theory of Economic Change (Cambridge, Mass., 1982); Paul David, "Understanding the Economics of QWERTY: The Necessity of History," in Economic History and the Modern Historian, edited by W. Parker (London, 1986), pp. 30-49; and Brian W. Arthur, "Competing Technologies and Lock-in by Historical Events: The Dynamics of Allocation under Increasing Returns," Economic Journal 99 (1989), pp. 116-131. 
nous and their articulation seldom harmonious. ${ }^{4}$ Most important, because their models of economies are abstracted from the social institutions in which societies (and hence economies) are reproduced, analyses that begin with blueprints ignore the ways in which actual policy makers are shaped and constrained by the citizens of the newly emergent democracies of East Central Europe. Capitalism cannot be introduced by design in a region where the lessons of forty years of experimentation by a rational hand have made the citizenry cautious about big experiments. A new social order cannot be created by dictation-at least not where citizens themselves want a voice in determining the new institutions. And these voices will be loudest where economic transformations are, as they must be in East Central Europe, painful and difficult. That is, attempts to reduce production costs and lower transaction costs can only be successful where society is willing to bear the transition costs. ${ }^{5}$

Because the actions of policy makers will be shaped by their perceptions of society's tolerance of these transition costs, we would do better to analzye the resources at their disposal for securing support for burdensome measures instead of focusing exclusively on their recipes for change. Such resources are not likely to be evenly distributed across the countries in the region. Even more important, these resources are not simply material, financial, or economic, but are above all political, as they entail the historically shaped patterns of mediation between state and society that differ qualitatively from country to country. In such a view, social change is not a process either directed from above or initiated from below but a result of interactions in which the designs of transformation are themselves transformed, shaped, and modified in response to, and even in anticipation of, the actions of subordinate

4. Sensitivity to these differences is obscured by the very events that brought so much attention to the region. "1989" was a double conjunture-both in the near simultaneity of events across the countries of the region and in the rapid acceleration and increasingly reciprocal effects of changes across political, economic, and social domains. But "1989" will stand in the way of understanding developments in the region if we take it as a universal beginning or culmination. That is, we must begin to disaggregate "the transition," perhaps even dispense with it as a concept, and undertake the difficult research work of understanding how changes in the different countries and in the different domains have very different temporalities. Changes in social institutions, for example, are not simply slower but might well have been taking place much before more easily observable political developments. If pace and timing differ across domains, we should also not assume that changes within them necessarily move in the same directions.

5. See László Bruszt, "Transformative Politics: Social Costs and Social Peace in East Central Europe," in this volume. 
social groups. ${ }^{6}$ By attending to these interactions, our examination shifts from preoccupation with the "one best way" to manage the transition scientifically to a more comparative analytic strategy deliberately attuned to diverse institutional configurations differing among the countries not in degree but in kind.

The third reason for skepticism about analyses that begin with blueprints is that they often take the "collapse of Communism" to indicate the existence of an institutional void. Indeed, this myth of "starting from scratch" explains some of the academic fascination with the region and the hasty proliferation of marching orders to create capitalism in six steps or sixty. But the devastation and destruction wrought by Communism and the explosive rapidity of the demise of its party-states have not left an institutional vacuum. My concern here is not with some lingering traces of socialist ideology or with the reconstructive surgery that gives new anatomies to the old nomenklatura but with the institutional legacies of the transitions themselves. To extend the metaphor of collapse: It is in the ruins that these societies will find the materials with which to build a new order; therefore, differences in how the pieces fell apart will have consequences for how political and economic institutions can be reconstructed in the current period. ${ }^{7}$ In short, it is the differing paths of extrication from state socialism that shape the possibilities of transformation in the subsequent stage.

The analysis below thus takes as its point of departure a proposition that is implausible only on first acquaintance-the economic transformations currently attempted in East Central Europe will be marked by "path dependence." The hypothesis is unlikely from the vantage of the drafting board where the designer sketches new institutions on a tabula rasa: Why should we expect continuities where departures are imperative? The true strength of the concept of path dependence, however, is precisely its analytic power in explaining outcomes where strategic actors are deliberately searching for departures from long-established

6. Unlike the designer's schemes in which the actions and preferences of subordinate social groups are a hindrance to the speedy enactment of the prescribed formulas (or at most take only a reactive role at the voting booth to approve or remove programs and parties), in the perspective adopted here the institutionalized interactions between state and society play a formative role in shaping actual strategies.

7. I take this to be the key analytic insight of Theda Skocpol's States and Social Revolutions (Cambridge, Eng., 1979). See László Bruszt and David Stark, "Remaking the Political Field in Hungary: From the Politics of Confrontation to the Politics of Competition," in Ivo Banac, Eastern Europe in Revolution (Ithaca, N.Y., 1992), pp. 13-55. 
routines and attempting to restructure the rules of the game. ${ }^{8}$ Actors who seek to move in new directions find that their choices are constrained by the existing set of institutional resources. Institutions limit the field of action, they preclude some directions, they constrain certain courses. But institutions also favor the perception and selection of some strategies over others. ${ }^{9}$ Actors who seek to introduce change require resources to overcome obstacles to change. This exploitation of existing institutionalized resources is a principal component of the apparent paradox that even (and especially) instances of transformation are marked by path dependence.

Such a view does not preclude the possibilities of changes that are far-reaching and dramatic. But it departs emphatically from those all too prevalent approaches that argue that economic development requires a rapid, radical, extensive (and even exhaustive) replacement of the current institutions, habits, and routines of the former centrally planned economies by an entirely new set of institutions and mentalities. Such wholesale replacement is rejected not because of some illusions or nostalgia for socialism but from an appreciation of the evolutionary character of capitalism (point one above). And if the massive social engineering that would be required to effect it is undesirable, it is also unlikely (point two). ${ }^{10} \mathrm{It}$ is for these reasons that I argue that the

8. As my emphasis on paths of extrication in the paragraphs above should indicate, by "path dependence" I am not referring to some processes whereby the societies of Eastern Europe are seen to return to the natural "historical trajectories" of the interwar period from which they had temporarily deviated (see, for example, the argument of Ivan Szelenyi in Socialist Entrepreneurs (Madison, 1988). Unlike these notions of already existing roads or the concept of trajectory in which one can calculate destination from knowledge of initial direction and thrust, the concept of path dependence is not that of a vector.

9. My conception of institutions as embodied routines and my emphasis on practices instead of preferences and on predispositions instead of rational calculations draws on the work of Pierre Bourdieu, especially, The Logic of Practice (Stanford, 1990). For a similar conception of institutions as not simply constraining but as enabling, see Paul DiMaggio and Walter Powell's introductory essay in The New Institutionalism in Organizational Analysis (Chicago, 1991), pp. 1-38.

10. The pertinent lesson of state socialism is that large scale social engineering might so badly tear the social fabric that its damage will take decades to repair and that a totalizing institutional uncertainty will preclude the longer term calculations so central to the efficient functioning of economic institutions. That is, the greater the scope of an experiment, the greater the risk of catastrophe. (See Murrell, in this volume.) My intention here is not to denigrate institutional design. Institutional designs do matter and can be for the better, especially if they are delimited in scope to solve particular problems of governance and coordination for specific sectors or localities (rather than as global solutions to the problems of an entire economy). In place of grand experiments, we should hope for more, not less "designs" - partial solutions to limited problems in which transformation becomes a process undertaken by a multiplicity of dispersed agents at many institutional sites. 
structural innovations that will bring about dynamic transformations are more likely to entail processes of complex reconfigurations of institutional elements rather than their immediate replacement.

From this perspective, we become more circumspect about such notions as "the transition to capitalism" or "the transition to a market economy" - alert to the possibility that behind such seemingly descriptive terms are teleological constructs in which concepts are driven by hypothesized end-states. Presentist history finds its counterpart here in futurist transitology. Thus, in place of transition (with the emphasis on destination) we analyze transformations (with the emphasis on actual processes) in which the introduction of new elements takes place most typically in combination with adaptations, rearrangements, permutations, and reconfigurations of already existing institutional forms.

This paper examines these transformative processes through a comparative analysis of strategies of privatization in the four East Central European economies: Czechoslovakia, Hungary, Poland, and the former East German territories. The purpose of such a four-way comparison is not to construct some essentialist model of privatization against which the respective cases differ only in degree but to produce a comparative framework in which the specificity of each case will be revealed through its simultaneous mutual contrast with the other cases. ${ }^{11}$ The comparative study of East European capitalisms is best launched not by taking its point of comparison in a general model of capitalism nor even of the plural models of existing capitalisms (in which the East European cases are various approximations of West European counterparts) but by an analysis in which the specific content of the analytic categories is developed through a relational comparison of the East European cases themselves. ${ }^{12}$ The privatization programs of the region offer an opportunity to adopt such a methodological strategy. Despite broad and pervasive similarities in the systemic problems encountered, there are significant differ-

11. For the use of a similar comparative methodology see David Stark, "Rethinking Internal Labor Markets: New Insights from a Comparative Perspective," American Sociological Review 51: 4 (August 1986), pp. 492-504; and David Stark, "Bending the Bars of the Iron Cage: Bureaucratization and Informalization under Capitalism and Socialism," Sociological Forum 4: 4 (1990), pp. 637-664.

12. This is the major limitation of Ellen Comisso's interesting argument in "Political Coalitions, Economic Choices," Journal of International Affairs 45: 1 (Summer 1991), pp. 1-29. For Comisso, the "options" available to the economies of Eastern Europe are given by the array of existing West European national economies, e.g., the "French model," the Swedish model," "modified Thatcherism," etc. 
ences in the privatization programs that typify transformative processes across the four national cases. In the concluding section, these differences in the first phases of transformation are traced to differences in the earlier stages of extrication. We shall see that these privatization programs are not derived from master blueprints but are shaped by the specific institutional resources that are the legacies of the path of exit from state socialism. Seen from this vantage point, transformative processes taking place in contemporary East-Central Europe resemble less architectural design than bricolage, construction by using whatever comes to hand.

\section{Specifying the Dimensions of the East European Variant(s)}

"Privatization" in this paper refers to the process of transferring ownership rights of productive assets held by the state. Although in the contemporary East European context such transfer is conventionally seen as the principal means of creating a private sector in an economy dominated by a public sector, the two processes should not be confused or conflated. First, transferring ownership from state to private hands is unlikely to be sufficient to create a dynamic private market economy. ${ }^{13}$ Second, such a marketized private sector might be more effectively produced by measures to stimulate the start-up of new ventures and expansion of existing units in the nascent private sector (formerly, the second economy) than by transforming state assets into private assets. ${ }^{14}$ Nonetheless, each of the new governments in the region looks to privatization, i.e., ownership transfer, as the fundamental step toward the creation of a market economy. This paper brackets the question of that causal relationship and focuses on the variation in privatization strategies across the cases. How do the ways these new governments differ in their policies for transferring ownership of the assets of state enterprises? While acknowledging similarities among the cases, it identifies the distinctive privatization programs that typify each new government's strategy of privatization during its initial period in office.

For a typology to portray these differences, I propose three dimensions reflecting three central questions that must be addressed by any program of privatization: (1) How are the state's assets evaluated? (2)

13. David Stark, "Privatization in Hungary: From Plan to Market or from Plan to Clan?" East European Politics and Societies 4:3 (Fall 1990), pp. 351-392.

14. János Kornai, The Road to a Free Economy (New York, 1990); and Stark, "Privatization." 
Who can acquire these assets? and (3) With what resources are ownership rights acquired? In the following section I specify the categories of these dimensions for the East Central European variant(s) of privatization strategies. ${ }^{15} \mathrm{We}$ then analyze the country cases and identify those programs exemplifying the various combinations of methods of asset evaluation, identities of participants, and resources for participation in privatization.

Valuation of Assets. The polarities of this dimension are straightforward. At one pole, assets of the large public enterprises are evaluated by administrative means. At the extreme we would find a single agency responsible, as part of the state bureaucracy, for every aspect of the privatization process. That bureaucratic agency would assess the economic viability of firms, selecting some for foreclosure and others for privatization, and would seek out buyers for those designated to be privatized. Although bureaucratic agents might solicit economic assessments of market performance when conducting these evaluations, actual decisions would be made on the basis of administrative measures rather than spontaneous market mechanisms. The other pole is already anticipated in our presentation of the first: valuation would take place directly through market mechanisms. Here policy makers do not see markets only as an outcome of privatization but also as a means of privatization. At the extreme we would find spot market transactions in the form of public auctions where auctioneers could, as with the sale of farm implements, announce a figure at which bidding could begin; but the final selling price would be determined by the competitive bidding.

The two poles, however, do not entirely capture the complexity of this dimension, for in between are some mechanisms of price formation and valuation that can be conceptualized either as combinations of bureaucratic measures and market mechanisms or as alternatives to them. Examples of such hybrid or alternative mechanisms would be

15. Rather than explicating these dimensions as a strictly logical deductive exercise, the analytic categories are given content in terms of the specific historical and social setting that is contemporary East Central Europe. The Weberian notion of historically grounded concepts should be familiar to most sociologists. My method here is antithetical to the hollow antinomies of "deduction versus induction" or "theory versus historicism" resuscitated in the recent rational choice literature, e.g., Edgar Kiser and Michael Hechter, "The Role of General Theory in Comparative-historical Sociology," American Journal of Sociology 97: 1 (July 1991), pp. 1-30. 
relational contracting (in which state agencies contract the task of privatization to consulting firms based on their international reputation or in anticipation of long-term associations in which agency and firm would share information through channels not easily expressed in market terms), or bargaining (a loose term denoting patterns in which price setting is strongly influenced by network connections that differ from purely market transactions or political considerations that differ from purely administrative criteria). ${ }^{16}$

Actors Targeted to Acquire Assets. In constructing a strategy of privatization, the new governments of these emergent democracies can present privatization as a process that will increase the wealth of the nation. Firms will be more accountable, more likely to economize on costs, and more oriented toward effective and efficient performance, they can argue, when property rights are exercised by private owners instead of state bureaucrats. But if privatization will increase the national income, it will also increase private wealth. Regardless of how they choose to portray private gain as contributing to the public good, governments that undertake privatization on a scale so potentially vast as that in contemporary East Central Europe (where over 85 percent of productive assets are state property) must address questions of distributive justice. ${ }^{17}$

We are thus interested in the question of whether these new governments will attempt to forge an explicit link between the economic objectives of privatization and the new civic principles of the emergent

16. On relational contracting and other forms of coordination between firms that lie between (or outside) the dichotomy of markets and hierarchies, see Oliver Williamson, The Economic Institutions of Capitalism: Firms, Markets, and Relational Contracting (New York, 1985); and Rogers Hollingsworth and Wolfgang Streeck, "Countries and Sectors: Concluding Remarks on Performance, Convergence, and Competitiveness," in Rogers Hollingsworth, Philippe Schmitter, and Wolfgang Streeck, eds., Comparing Capitalist Economies: Variations in the Governance of Industrial Sectors (New York, 1992).

17. Strategies of justification thus lie at the core of strategies of privatization. Although I raise these issues explicitly in this subsection, processes of justification are an important aspect of each of our three dimensions. My intention here is not to unmask them as after-the-fact ideologies or false rationalizations mystifying some underlying injustice but to see how the specific work of justification can vary from case to case as shaped by the broader transformative politics. On strategies of justification in the transitional period on the shop floor, see David Stark, "La valeur du travail et sa rétribution en Hongrie," Actes de la recherche en sciences sociales 85 (November 1990), pp. 3-19 (available in English as "Work, Worth, and Justice in the Hungarian Mixed Economy," Working Papers on Central and Eastern Europe, Center for European Studies, Harvard University, 1990, no. 5). For an ambitious theory of justifications see Luc Boltanski and Laurent Thevenot, La justification: Les economies de la grandeur (Paris, 1991). 
democratic polities. Specifically, is citizenship (that most fundamental civic principle with its attendant concept of the abstract equality of the citizen) invoked as a principle for distributing property rights? At issue is not whether individuals are favored over collectivities but whether individuals are explicitly targeted in their capacity as citizens to be recipients of property rights in the privatization of the assets of the large public enterprises.

Whereas some governments will utilize civic principles to target citizens as recipients of the state's former assets, others will utilize purely economic principles to target corporations. In this latter case, although private persons might participate in some programs of privatization (in agriculture, in the "small privatizations" of retail shops and restaurants, for example), the fundamental strategy of the privatization of the large state enterprises will be based on distributing property rights to incorporated units. In short, privatization strategies will differ according to whether the state specifically seeks to involve civic persons (citizens) as participants or, alternatively, eschews civic principles in favor of designing large-scale privatization around legaleconomic persons (corporations).

Resources Utilized to Acquire Ownership Rights. Privatization strategies can also vary according to the kinds of resources that are utilized (we might say converted) to acquire ownership rights. Monetary or financial resources are the obvious first category along this dimension. But, in addition to being differentiated according to their financial holdings or monetary savings, actors in the transitional societies of East Central Europe also differ according to the powers and capacities invested in their positions. In fact, the prohibition of private property in productive assets meant that the stratification systems of state socialist societies were organized more around differences in positions than in wealth. Thus, at the very moment when these economies embark on privatization, they must deal with a continuing legacy of the stratification system of state socialism: society is not greatly differentiated according to wealth in a system where advantages accrued to positions.

Thus, our third dimension contrasts those privatizations schemes and strategies that are organized primarily around the utilization of monetary (including credit or other financial) resources with those in which the participating agents capitalize on their positional resources. 
The concept of position and that of "positional property," of course, carry connotations of office holding. ${ }^{18}$ We also start from that Weberian conception, but we will find it useful as well to extend the application of the concept from office holding to a broader set of organizational posts and locational positions. We should stress that our attention to positions should not be interpreted as a narrow preoccupation with the fate of those who held political positions in the old order and whether and how they are converting their political capital into economic capital. ${ }^{19}$ Our concern here is more with economic job holding than with political office holding. Some privatization strategies will be structured in such a way that the occupants of certain positions will be able to utilize that occupancy for advantage in acquiring property rights. Managers, for example, might be able to utilize positional resources to gain effective ownership rights. Similarly, privatization strategies that place importance on employee ownership plans are instances of inclusion/exclusion in which ownership rights are acquired through positional resources.

Our three dimensions are cross-classified in Figure 1 to yield a preliminary typology of privatization strategies in East Central Europe. The dimensions referring to actors targeted to acquire assets and resources to acquire ownership rights form a two-by-two table. The remaining dimension referring to the method of evaluating assets is represented through shading ("administrative" lightest and "markets" darkest with "bargaining" in between). Also located on Figure 1 are those strategies for privatizing large public enterprises that most closely exemplify four of the possible combinations of the categories along the three dimensions.

18. We think obviously here of the work of Pierre Bourdieu on different forms of "capital" in modern societies. See, for example, his "Forms of Capital" in John G. Richardson, ed., Handbook of Theory and Research for the Sociology of Education (New York, 1986), pp. 241-258. On positional property and its conversion in the Chinese setting see Victor Nee, "Social Inequalities in Reforming State Socialism: Between Redistribution and Markets in China," American Sociological Review 56 (1991), pp. 267-282.

19. The old political capital suffered a massive devaluation and, in the current period, the publication of memoirs is one of the few remaining avenues of such direct conversion. In fact, there are good reasons to expect that in the current period monetary rather than positional resources will be more important as an avenue to ownership for those former apparatchiks whose earlier assets were exclusively political (that is, whose political capital had not already been combined with certain forms of cultural capital to yield economic positions in the managerial ranks). 
Figure 1. A typology of privatization strategies in East Central Europe

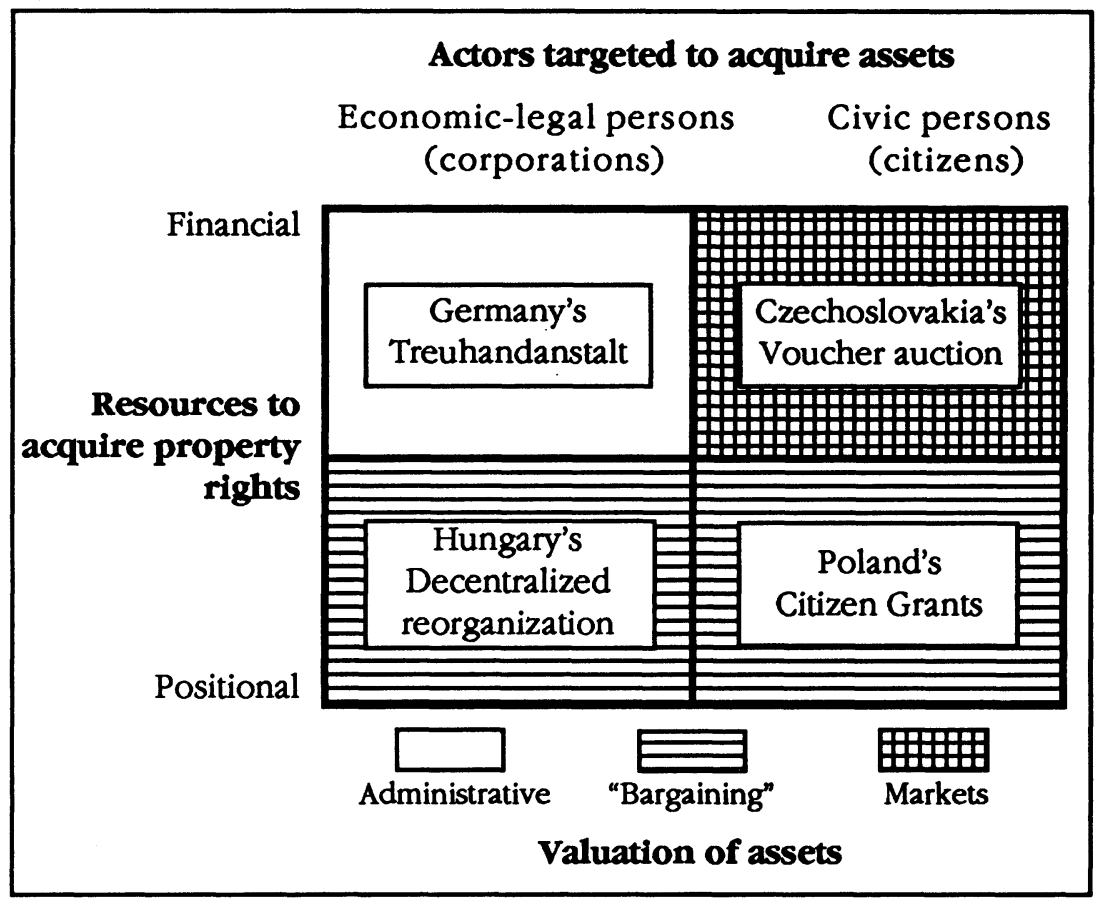

To avoid possible misunderstandings in interpreting this typology, we should state at the outset how we have delimited its object of study. First, the typology addresses questions of the privatization of large public enterprises. That is, we have not included here the multitude of schemes for privatizing retail trade, catering establishments, and agricultural cooperatives. ${ }^{20}$ Second, our decision rule for placing country cases within the typology was to find cases that exemplify particular intersections of its dimensions. Our task here is to identify distinctive traits rather than produce an exhaustive description of the full range of privatization programs in each country. Thus, location of a particular

20. A more comprehensive examination would also necessarily have to address the disposition of real estate and the question of the reprivatization of property. Restitution or compensation of former owners is an important question with significant implications for the timing, pace, and methods for privatizing the large public enterprises. In particular, uncertainties about reprivatization can pose serious obstacles that inhibit potential buyers and delay privatization in the state sector. For an excellent analysis of the politics of compensation in Hungary see David L. Bartlett, "The Political Economy of Privatizaton: Property Reform and Democracy in Hungary," in this volume. 
country case in a given cell of the typology is not meant to capture all aspects about its course of privatization. ${ }^{21}$ Third, our typology focuses on the strategies of policy makers in approximately the first year of the newly elected governments. How these strategies will be reshaped in the course of interactions with the relevant social actors must be the subject of a separate, and later, investigation.

\section{Distinctive Features of the Country Cases}

\section{Germany's Treuhandanstalt.}

Our discussion of the typology of privatization strategies represented in Figure 1 begins with the position denoting the administrative evaluation of assets favoring corporate actors utilizing predominantly monetized resources. No privatization strategy better exemplifies this particular combination of elements than the institution of Germany's Treuhandanstalt. Charged with the task of performing triage on the wounded enterprises of the formerly East German economy, the Treuhandanstalt or Trust has single-handedly carried out functions that are performed elsewhere in the region by diverse governmental units scattered across the ministries of Industry, Planning, Finance, Labor, and Privatization. Following the monetary union of the two Germanies in July 1990 and their unification on October 3,1990, the Treuhandanstalt became the world's largest industrial holding with a staff of 2,500 to privatize and monitor the operations of the former East German state enterprises employing more than 3 million wage earners. ${ }^{22}$ By May of 1991, the Trust had privatized 1,670 firms out of the approximately 7,000 that had been operating in the former East German lands, taking its largest strides in the branches of energy, food stuffs, construction, trade, and tourism. Ninety percent of these properties were sold to West Germans

21. For example, our location of "Hungary's decentralized reorganization" in the lower left hand cell indicates that policy makers there have, to date, designed ownership restructuring around corporate owners, through bargaining processes, favoring positional resources. It does not imply, for example, that financial/monetary resources are not mobilizable in Hungary nor that positional resources are not mobilizable in Germany. Similarly, the use of citizen vouchers in Poland and Czechoslovakia does not exclude incorporated actors from participation in privatization in those economies - although it is interesting to note that the governments of Germany and Hungary have, thus far, excluded the principle of citizenship from their strategies for privatization.

22. The World Bank/CECSE 2: 5 (May 1991), p. 3. 
(primarily corporations), five percent were purchased by foreign (that is, non-German) capital, and five percent are now held by their former managers. In preparation for further privatizations, the Treuhand also split up 316 Kombinat (mega-conglomerates in the old socialist economy) into 8,500 smaller firms involving some 45,000 plants. ${ }^{23}$

This aggressive posture of attacking a problem by means of a strong bureaucratic agency with an almost unquestioned mandate to impose radical, sweeping, and rapid restructuring is the defining feature of the German privatization strategy. But if the German state has moved with greater speed and determination than other Central European governments in the first stage of privatization, there are indications that its greatest difficulties still lie ahead. Recent developments indicate that these obstacles will not be met with an even quickened pace and stronger administrative measures but that the difficulties facing the Treuhand will retard its speed and lead to modifications of its methods.

The irony of the East German case to date has been that the very strength of the West German economy that was presumed to yield a more smooth transition (relative to its neighbors) has proven in the initial stage to be also a source of problems. In particular, the dramatic surge of demand for consumer goods in the newly incorporated lands was met in the first instance by expansion of output by West German firms. Thus, if it indeed might be the case that the "wealthy brother" will save the situation by buying firms in the long run, in the short run he began by selling goods to his desiring and poorer siblings. Uncompetitive on the world market, unable to sell goods on the West German market, and now uncompetitive on their own territory, the former East German enterprises saw their markets evaporate within weeks. With no orders and no work, millions of employees in these failing enterprises have been receiving a scarcely disguised unemployment compensation in the form of "short-time work" in which they remain on the payroll with little or nothing to do at their place of employment. ${ }^{24}$

23. For an excellent description of the work of the Treuhand in its first months of operation and a balanced analysis of the difficult problems facing it in the near future see Roland Schönfeld, "Privatization in East Germany: Strategies and Experience," (Paper presented at the Conference on Transforming Economic Systems in East-Central Europe, Munich, June 1991.)

24. Such short-time work was originally scheduled to expire on June 30,1991, prompting some estimates that there would be 3.5 to 4 million unemployed (as high as 45 percent of the previously active earners in 1989) by the end of the summer of 1991. See, Schönfeld, "Privatization." These worst nightmares were not realized, in part, because short-time work was extended beyond that deadline. By late 1991, high-level Treuhand officials acknowl- 
For some intellectuals who attempt to shape German public opinion, the most attractive solution to this problem is massive migration. "Everyone who is willing to work hard can find a job here in our prosperity," they can be heard to say. But even if such westward migration could absorb a significant proportion of those seeking work, the consequences might prove not only catastrophic to the social fabric but also devastating to the local economies they leave behind. Massive migration, even on a scale far lower than some policy makers have in mind, could lead to a massive devaluation of the human capital of the economy of the former East German lands. Such devaluation would be triggered not simply by the aggregate loss of highly skilled individuals but also by the destruction of the work teams in which those skills had previously been utilized. Not as a direct outcome of foresight and planning but as an unintended consequence of the macroeconomic mismanagement of state socialism, the organization of work in the micro sphere of the redistributive enterprise had evolved into a forced autonomy and a distorted flexibility. ${ }^{25}$ At the level of the shop floor, work teams developed, indeed were forced to develop, patterns of adaptation to adjust quickly and flexibly to supply shortages and other irrationalities of central mismanagement. Such adaptations should not be idealized-they were constrained and distorted-but they had evolved into work units in which the human capital of the teams was more than the sum of its individual parts. In such a case, the departure of two or three from a team of a dozen can cripple its functioning and shatter a small but potentially significant resource that might otherwise be a basis for reconstructing a failed economy. In short, migration stimulated by the close proximity to prosperity on the same national territory might alleviate unemployment but it might also erode organizational capacities and retard the development of a dynamic economy in the former East German lands.

Unemployment and severe economic crisis will have important conse-

edged an effective unemployment rate of about 30 percent. See Horst Kern and Charles F. Sabel, "Between Pillar and Post: Reflections on the Treuhand's Uncertainty About What To Say Next," (Paper presented at the Conference on the Treubandanstalt, Harvard University, November 1991; and comments by Treuhand officials at that conference.)

25. Stark, "Rethinking," and János Lukács, "Organizational Flexibility, Internal Labor Market, and Internal Subcontracting, Hungarian Style," in Rudolf Andorka and László Bertalan, eds., Economy and Society in Hungary (Budapest, 1986), pp. 15-34. 
quences for the further work of the Treuhandanstalt. As the situation inside the Eastern enterprises rapidly deteriorates, it will prove increasingly difficult to find buyers for them. Meanwhile, as unemployment explodes to unprecedented proportions, pressures will mount to slow the pace of liquidation. Firms that can be neither sold nor shut down (and we can expect that they will number in the thousands) will remain under the bureaucratic authority of the Treuhand, and that state agency will be forced to intervene directly in reorganizing these properties using subsidies to keep them afloat in the meantime. ${ }^{26}$ But we can further expect relentless pressures on the Trust to demonstrate that it remains committed to a determined course of privatization. After all, its mandate was for sweeping and rapid privatization-federal politicians and other governmental officials will not look favorably on an agency that resorts to subsidizing instead of privatizing, and bureaucratic superiors will frown at subordinates in the agency whose quarterly record of completed privatizations falls below the norm. From the combination of these factors, we can expect that the Treuhandanstalt will increasingly look to the current managers as a potential pool of new owners for the failed but recuperable smaller units that have already been (or soon will be) broken off from the large state enterprises. In this scenario, the evaluation of assets is likely to take place increasingly through bargaining between the agency and enterprises with managers utilizing positional resources to exercise new and expanded property rights. A recent study indicates that this process has already begun, and restructuring has become the critical task of the Treuhand. To organize the market for potential buyers, firms must first be reorganized. ${ }^{27}$ The Kombinate are too big to sell all of a piece; and the parts that can be broken off and sold by themselves are too small to make a difference. Restructuring thus often entails the simultaneous disaggregation of several large enterprises and the strategic recombination of these newly available constitutive parts (from across different enterprises) to create new ventures.

\section{Czechoslovakia's voucher-auction program.}

In strong contrast to the decidedly statist orientation of the German privatization strategy, the Czechoslovak strategy is an exemplary case

26. Schonfeld, "Privatization," and Kern and Sabel, "Pillar and Post."

27. Kern and Sabel, "Pillar and Post." 
of evaluating assets directly by the market, involving participation on the basis of citizenship, and utilizing monetary resources. In fact, this particular combination of categories along our three dimensions is represented in a single institutional innovation in the Czechoslovak strategy - the use of citizen vouchers in public auctions of shares of the large state enterprises.

The program that the Czechoslovak economic authorities are proposing will involve the distribution of over fifty percent of the equity of more than a thousand large public enterprises through a citizenship voucher scheme. Each Czechoslovak citizen over eighteen years of age will receive vouchers equal to a thousand "investment points." These investment points can be exchanged for shares in the enterprises designated for privatization through the voucher program. But, if every citizen receives these vouchers as a matter of right, only those who pay a registration fee of a thousand korunas will be able to use the vouchers in the public auctions. ${ }^{28}$ To indicate that the equity shares obtained through the voucher program are emphatically not a free gift from the state, to signal that there will be risk involved, and to filter out citizens with no serious interest in share ownership, the Czechoslovak officials have designed a voucher scheme that combines citizenship participation and monetary resources.

The actual process of exchanging vouchers for shares is fairly complex (and the Czechoslovak authorities are undertaking a major program to educate the public about its basic principles and its logistical intricacies). The first round of the voucher-auction is scheduled to begin on March 16, 1992. By that time the Ministries of Privatization will have designated the enterprises whose equity will be distributed through auction. ${ }^{29}$ For each enterprise, the Ministries will post an initial asking price for the shares of that particular firms. To understand the principles of the auction, it is important to note that this "price" is not expressed in monetary units but in terms of investment points. Basically, the state announces the number of investment points at which it is willing to exchange a share of a given enterprise. A single

28. Presumably to increase participation rates, the registration fee has been reduced from initial proposals that called for 2,000 korunas (equivalent to about half the average monthly earnings of industrial employees).

29. By late 1991, the Ministry had received 3,588 privatization projects from some 900 enterprises. Some 2,800 of these projects were in conformity with the requirements of the voucher scheme. I am grateful to Gerald McDermott for providing these figures. 
share of a blue-chip company, for example, might begin at an initial level of two hundred investment points; a share of a firm with a less prominent record or less promising future prospects, on the other hand, might be posted at only ten investment points. In the first round of the auction, then, one citizen might decide to place all of his one thousand investment points on five shares of the blue-chip company; another could indicate his willingness to exchange all of his one thousand points for one hundred shares in the less promising venture; and a third could diversify his "portfolio" of investment points across firms with differing initial asking prices.

Equally important in understanding the principle of asset evaluation represented in the voucher-auction, it should be stressed that the auction is conceived as an iterative process occurring in multiple rounds. That is, although the economists in the Czech and Slovak Ministries of Privatization must conduct a rough and ready evaluation of the performance of firms to set the initial price of shares in the first round of bidding, the final price in investment points in the simulated market of the voucher-auction (and, more importantly, the later price of shares bought and sold on an actual market) will be determined by the supply and demand for these shares. What Vaclav Klaus and his team in the Ministry of Finance seem to have in mind is a kind of Walrasian auctioneer. ${ }^{30}$ The auctioneer (actually a computerized network) accepts offers to buy shares of a given enterprise at a certain asking price in investment points. Unlike a commoditites exchange (or the typical auction we might know from an estate sale or of objects of art) the bidder-citizens are not, strictly speaking, bidding up the price in a given round. At the end of the first round, the auctioneer identifies those shares for which demand exceeded supply as well as those in which the reverse was the case. (To take a hypothetical case, the number of citizens willing to expend two hundred of their investment points for a share in the blue-chip corporation exceeded the number of shares being issued for that enterprise, or vice versa.) As the seller, the state can then accept offers from that round, or adjust prices upwards or downwards for the next round to be held two weeks later. The auction proceeds for three of four rounds

30. We might also observe that the auction that Klaus is proposing has some resemblance to the schemes of Oscar Lange for setting prices through a simulated market within a socialist economy. 
with the state accepting offers or revising prices. One concept currently in circulation among the designers of the voucher-auction program is that the state should accept offers where the demand for shares of a particular enterprise is lower than their supply (the number of shares for each firm in the auction is fixed) and revise prices upwards for those shares where demand exceeds supply.

This is not the place to elaborate all the technical and political complexities of the voucher-auction. What percentage of assets will the state retain even for the auctioned firms and how will this influence the bidding process? What are the likely consequences of different decision rules about when the state should accept offers or when to revise "prices" upwards or downwards? What if the overall participation rate is so low that virtually all shares are undersubscribed? ${ }^{31}$ Our attention here is instead addressed to the major principles that underscore the voucher-auction as an important feature of the Czechoslovak strategy of privatization.

First, and most important, the Czechoslovak leadership appears committed to using a simulated market to rapidly achieve an actually functioning equity market in the shares of a significant proportion of the former state enterprises. ${ }^{32}$ The question of whether "investment points" reflect the real value, even a true relative value, of shares is quite beside the point since the purpose of the voucher-auction is to get shares in private hands where they can be actually bought and sold. ${ }^{33}$ According to the designers of the auction, it is in such a market (where speculators are not to be disparaged but encouraged) that the real

31. According to public opinion polls at the beginning of 1991 , interest in participating in the voucher-auction program was very low. See, Franz-Lothar Altmann, "Privatization in Czechoslovakia." (Paper presented at the Conference on Transforming Economic Systems in East Central Europe, Munich, June 1991). For an excellent account of the economic landscape in which the Czechoslovak privatization programs are occurring, see Gerald A. McDermott and Michal Mejtrik, "The Role of Small Firms in the Industrial Development and Transformation of Czechoslovakia," Small Business Economics 4 (1992), pp. 51-72.

32. The Czechoslovak leadership, moreover, appears prepared to accept relatively high transaction costs (the voucher-auction will be complicated and costly) in the distribution of shares in its privatization strategy in anticipation that these one-time transition costs will quickly reduce overall transaction costs in the newly privatized economy.

33. To the problem that the citizenry might not have information about the market the Czech strategists also seem to have a market solution in mind; investors who take risks will want better information and the demand for information will stimulate some to get into the business of gathering and selling information. The simulated market, they believe, will help to set in motion the secondary institutions (brokerage houses, market analysis, etc.) required for smoothly functioning capital markets. 
evaluation of assets will take place. ${ }^{34}$ It is for this reason, rather than primarily because of the registration fee, that we locate the Czechoslovak privatization strategy in that cell representing the intersection of market evaluation and monetary assets. ${ }^{35}$

Second, with the establishment of a capital market organized around the stock exchange stimulated by the voucher-auction program, the Czechoslovak economy appears to be heading in the direction of raising investment funds through markets (typical of the Anglo-American system) rather than through the Japanese or German system in which banks play a more central role in monitoring and directing the performance of their creditor firms (for a contrast, see the Polish case below).

Third, the Czechoslovak leadership appears prepared to accept relatively dispersed ownership in the initial stage of its privatization program in hopes that later transactions in the actual capital market will yield relatively rapid concentration of ownership in mid-level enterprises. Several design features currently being discussed (the combination of offering the shares of some firms at initial low asking "prices" and accepting offers where the supply of shares exceeds demand) suggest that the Czechoslovaks are hopeful that some enterprising individuals will quickly buy up these relatively cheap shares and gain controlling interest in these firms. Such a scenario would most likely be accompanied by continuing dispersed ownership in the most highly prized enterprises where the economic leadership presumably has more confidence in the enterprises' managerial talent and is therefore more willing to tolerate the managerial control that comes with highly diffused shareholding. ${ }^{36}$ These same features also suggest that the Czecho-

34. Prominent among the Czechoslovak citizens who will have money to speculate on the stock exchange that is to be the product of the voucher-auction will be former Communist officials and black-marketeers. The cynicism of the architects of the Czech privatization strategy is undisguised: "It's sure there is dirty money here," said Tomas Jezek, Czech Minister of Privatization. "But the best method for cleaning the money is to let them invest it." New York Times, January 27, 1991, p. 10.

35. The architects of the Czechoslovak voucher-auction programs hope that a simulated market will stimulate a market. There is an element of learning by doing built into the program. By playing the voucher market (and this is really playing a game) at least some groups of citizens get accustomed to "buying and selling" and might be drawn into really playing the market. (For a very different conception, see the Polish case below which highlights the distinctiveness of the Czech case.) The question of whether the institutions of a stock exchange can be created in such a manner, of course, remains to be tested.

36. For those enterprises at the very bottom of the list (where citizens were not willing to exchange points for shares) the state will, of course, face the difficult decision of whether to close them or to continue operating them under state management. 
slovak leadership is aware of the likelihood of resistance to the voucherauction on the part of managers of the enterprises designated for auction and is designing some features of the program in attempts to neutralize or mitigate this resistance. At the bottom end, firms whose shares find no buyers might be more easily liquidated after a strong vote of "no confidence" by the citizen "investors." At the top, economic officials can point to the likelihood of diffused shareholding in the bluechip companies to persuade their managers (precisely the ones with the most bargaining power) that the auction is not against their interests and should not be resisted. ${ }^{37}$ For that broad range of enterprises in between, the Czech ministers can probably count on resistance from managers, but they seem to hope that relatively quick concentration of ownership will bring these firms under control of the new owners.

\section{Poland's universal citizen grants and employee shareholding}

The story of Poland's privatization strategy begins in Gdańsk, the birthplace of the first and, for a time, the largest independent trade union in Eastern Europe. But Solidarity and the most famous offspring of the Lenin shipyards who is now the president of the Polish Republic are only half the story. Not without historical irony yet not entirely by coincidence, Gdańsk was also the birthplace of Polish neo-liberalism. During the mid-1980s, while the intellectuals of Warsaw and Budapest debated in urban coffeehouses, a group of young private businessmen and young provincial intellectuals in Gdańsk formed a Liberal Club and at its meetings began reading and discussing major theoretical statements on property rights. From the practical experiences of these entrepreneurs and the circle of intellectuals close to them arose the Liberal Congress, a small but extraordinarily influential party that has produced Jan Krzysztof Bielecki, the former Prime Minister and a disproportionate share of cabinet ministers in the government formed after the election of President Wałęsa.

Privatization in Poland, of course, did not begin under the leader-

37. Anticipation of managerial resistance would lead us to expect that there should be active bargaining between ministries and enterprises in the initial asset evaluation determining the initial asking "price" in the first round of the auction. Such an observation does not threaten our typology since that initial asset evaluation is only a preliminary one to set in motion the auction (and the later market for shares) in which the effective and determinate asset evaluation will take place. 
ship of Wałęsa's Polish liberals but instead under Jaruzelski's Polish Communists. During the power vaccuum of 1989 , an untold number of apparatchiks landed comfortably ("not peristroikists but parachutists," went the expression) as the new owners of promising units carved out of the former state enterprises. The liberals thus came to office (first with Finance Minister Balcerowicz and later with Bielecki's larger retinue) in a period in which the scandals of such "nomenklatura capitalism" could be heard in public circles, narrow and wide. Property reform was clearly on the agenda; and the Mazowiecki government announced a program of clean privatization, with the promise of attracting foreign investors and a series of large public offerings along the British model at its centerpiece. But foreign investors were slow and few (looking more to Hungary and, for different reasons, to Eastern Germany) and the public offerings made little dent in the state-owned assets of the large socialist enterprises. In fact, the major achievement of the first year of the Ministry of Property Transformation (a few unrepresentative foreign buy-outs aside) was privatization through liquidation - a dubious achievement, given the stated aims of the Ministry, since the assets of 159 of these 160 so-called privatizations were leased to the managers and employees of the liquidated firms. ${ }^{38}$

After the election campaign in which he had promised "acceleration," President Wałęsa turned to Janusz Lewandowski, the new Minister of Property Transformation from Gdańsk, asking him to elaborate and concretize the sweeping program for "mass privatization" that Lewandowski had proposed years earlier together with his Gdańsk compatriot, Jan Szomburg (currently, Director of the Research Center for Marketization and Property Reform). ${ }^{39}$ The young transformers confronted two obstacles. First, from the other side of the Gdańsk story, they faced the Workers' Councils, reactivated after 1989, who saw property trans-

38. See Jan Szomburg, "Poland's Privatization Strategy," (Paper presented at the Conference on Transforming Economic Systems in East-Central Europe, Munich, June 1991). For an overview of the ambitious goals but limited achievements of the early privatization efforts in Poland, see Tomasz Gruszecki, "Privatisation in Poland in 1990," Communist Economies and Economic Transformation 3: 2 (1991), pp. 141-154.

39. Lewandowski and Szomburg had proposed a stock distribution plan as early as 1988 . See their "Uwlaszczenie jako fundament reformy spoleczno-gospodarczej" (Property change as a fundamental aspect of socio-economic reform) in Propozyce Przeksztalcen Polskiej Gospodarki (Warsaw, 1989), pp. 63-81. A similar program of mass privatization was later elaborated by David Lipton and Jeffrey Sachs, "Privatization in Eastern Europe: The Case of Poland," Brookings Papers (1990), pp. 293-341. 
formation as their opportunity to solidify employee ownership. ${ }^{40} \mathrm{Sec}$ ond, they faced the enormous problem that domestic savings could cover only a fraction of the assets of the large state enterprises. On this subject Lewandowski had been heard to comment before accepting his new position that "privatization is when someone who doesn't know who the real owner is and doesn't know what it's really worth sells something to someone who doesn't have any money." 41

The program of mass privatization formally announced in June 1991 calls for the property transformation of some four hundred Polish enterprises in the first stage of its operation. Contained within the program is a major peace offering to the Workers' Councils: employees in the privatized firms will receive gratis 10 percent of the shares of their companies. That is, lacking savings and credit, employees will be able to use their positional resources as job-holders to gain an ownership stake in their enterprises. ${ }^{42}$

At the center of the mass privatization program, however, stands a universal citizenship grant in the form of share vouchers issued to every Polish citizen. In marked contrast to the Czechoslovak program, no registration fee is required to participate. By this signal, and through all its rhetoric, the Polish government seems eager to send the message that this is emphatically a free gift from the state.

Unlike the Czechoslovak schemes, moreover, the Polish citizen will not exchange his vouchers directly for shares in a privatized enterprise. Instead, the vouchers will be exchanged for shares in one or another "asset manager" who will, in turn, exchange the vouchers for shares in the transformed enterprises that it chooses (or is assigned) to manage. Current proposals call for this role to be played by experienced foreign companies, perhaps as few as ten in number. These asset managers,

40. Ownership claims coming from the Workers' Councils spring in some places from strong bargaining positions while in others from weakness. For an excellent analysis of reorganization at the level of enterprises that cautions against any global statements about the activities of "workers," "trade unions," or "management," see Janusz Dabrowski, Michal Federowics, and Anthony Levitas, "Stabilization and State Enterprise Adjustment: The Political Economy of State Firms After Five Months of Fiscal Discipline" Working Papers on Central and Eastern Europe, Harvard University, 1990.

41. Szomburg, "Privatization Strategy."

42. Debated but not yet resolved is the question of whether Workers' Councils will be disbanded in all transformed enterprises. If so, workers would be asked, in effect, to exchange a set of implicit organizational rights inherited from the transition period for a set of explicit ownership rights in the new period of transformation. The question will not be answered without much bargaining. 
large holdings of many of the largest firms, should not be confused with the managers of pension funds or mutual funds with which they bear only superficial resemblance. According to the intentions of the program's designers, these asset managers will not influence firms indirectly by buying and selling shares on the market but, instead, exercise authority through active and aggressive property management directly involved in formulating the policies and business strategies of the firms under their ownership control. ${ }^{43}$ Thus, in place of the Czechoslovaks' imitation of Anglo-American practices, the Poles seem to be looking to models in Germany and Japan. ${ }^{44}$

Several other features of the Polish program of mass privatization complete the contrast to the Czech voucher schemes. According to Polish officials and experts, the situation in the immediately foreseeable future is not likely to be developed enough to establish an "openended" program in which citizens are free to withdraw shares and change asset managers. Presumably to avoid inflation, citizens will be initially limited to collecting dividends from the results of the voucherasset manager program. That is, for an indeterminate period (but certainly lasting for several years) citizens cannot capitalize their shares by turning them in for their nominal value. The system is further "closedended" by prohibiting citizens from changing to a different asset manager. Because they will not be exposed to the discipline of disappointed share-holders who seek higher dividends elsewhere, the mass privatization program will include a complex incentive program for the executives of the limited number of asset managing companies. The hopes, meanwhile, are that the managers of the former state enterprises will now be under the firm discipline of the foreign asset managers. Obviously more concerned than the Czechs about the consequences of dispersed shareholding, the Poles are hoping to target citizens as "owners" while using the universal citizenship grant as a vehicle to achieve extraordinarily concentrated corporate control.

Thus, with its unrestricted access, the Polish voucher program is more inclusive than the Czechoslovak schemes. Yet its citizens' partici-

43. See, for example, Janusz Lewandowski and Jan Szomburg, "The Strategy of Privatization," (Paper presented at the Research Centre for Marketization and Property Reform, Gdansk, October, 1990.)

44. The distinction betwen "credit based" and "capital market based" (roughly, banks versus a stock exchange) is presented in John Zysman, Government, Markets, and Growth (Ithaca, 1983). 
pation is almost entirely passive. What can the Polish citizen do with his share? He cannot capitalize it, nor can he withdraw that share from his current asset manager and deposit it with another. In exchange for his passivity he gets a dividend, and that alone.

But why then have a voucher program at all? The answer lies in the goals of the Polish program to yield aggressive property management to foreign companies within the constraints of a politicized citizenry. No Polish politician or official could propose an outright give-away of Polish firms to foreign asset managers, and, strictly speaking, this is not what they will do. In a legal and political sense, they will have given the ownership to the Polish citizenry and the stewardship of the citizen-owned assets will rest in the hands of presumably competent managers. The Polish voucher program will not be "popular capitalism" in the sense of millions of small active investors with an interest in the ups and downs of the market. Instead, its designers hope to increase the chances that a capitalism with quite concentrated effective ownership can be made popular with the Polish citizenry. ${ }^{45}$

\section{Hungary's institutional cross-ownership.}

The fourth cell in our typology is exemplified by Hungarycharacterized by the combination of bargained evaluation of assets, corporate owners, and positional resources. Although Hungary's centralized State Property Agency (SPA) has a strong legislative mandate (and a firmly-established bureaucratic office) to supervise and control all aspects of the privatization process directly, asset evaluation in Hungary is not conducted through administrative means as in Germany. And although the shares of Hungarian firms can be sold on an embryonic stock exchange, the evaluation of assets, unlike the propos-

45. By late 1991, Poland's program of mass privatization showed signs of unravelling. The 400 firms scheduled for the voucher program had been reduced to 230 , and the program was under attack from all quarters. See Ben Slay, "Privatization and De-Monopolization in Poland," unpublished manuscript, Research Institute, Radio Free Europe/Radio Liberty, November 1991. If citizen vouchers recede in importance, we should expect that the locus of privatization/reorganization will shift even more to the level of firms and localities and especially to the Workers Councils - one of the most important institutional legacies in the economic realm of Poland's extrication from state socialism. For an excellent analysis of decentralized reorganization in Poland, see Janusz M. Dabrowski, Michal Federowicz, and Anthony Levitas, "Polish State Enterprises and the Properties of Performance: Stabilization, Marketization, Privatization," Politics and Society 19: 4 (1991), pp. 403-437. 
als for auctions in Czechoslovakia, is not primarily performed by market mechanisms. As a case that is in between the polarities of administrative and market evaluation, it is represented in Figure 1 as "bargaining," yet this residual or negative definition fails to convey the more precise institutional character of asset evaluation performed by the Hungarian authorities. In the spontaneous and controlled transformation of property rights that is occurring through decentralized processes initiated by the large public enterprises, bargaining is indeed the prevalent modality. But within the State Property Agency itself, and especially for the very largest firms designated by that agency to be sold to foreign investors in hard currency transactions to reduce the state deficit, the mechanism of asset evaluation would be more accurately characterized as relational contracting.

Within months after taking office in the spring of 1990, Hungary's coalition government under Prime Minister Jozsef Antall of the leading party, the Hungarian Democratic Forum, responded to the criticisms of the opposition parties by adopting the opposition's call for the "privatization of privatization." The central feature of this measure was a dramatic increase in the role of international investment banks and leading consulting firms in the privatization of the large state enterprises. When it nominated a list of twenty enterprises to be sold in the first round of privatization, the State Property Agency also announced an open invitation to investment banks and consulting firms to place proposals with the agency indicating, in general terms, how they would evaluate assets, arrange credit, and find a buyer for a given enterprise. That is, the agency put up for tender the rights to manage the restructuring of a particular company. The investment and consulting firms that won this competition would be compensated with a percentage of the final selling price. In an important sense, the SPA was not directly selling enterprises but instead selling the rights to lead and manage their privatization.

Dozens of consulting firms and investment banks responded to these tenders as whole rooms in the Property Agency were stacked high with proposals from floor to shoulder height. Among them, several of the most internationally prominent firms (Solomon Brothers, Goldman Sachs, Barclays, Price Waterhouse, Coopers and Lybrand, and others) had submitted prospectuses for eight or even more of the tenders. Each thought that, if selected on its merits, the firm would be leading 
several of the reorganizations. But when the SPA announced its decisions only three weeks later, it became obvious that its assignment of the tenders was based less on careful reading of the proposals than toward the aim of maximizing the number of cooperating partners in the first round: the twenty enterprises slated for privatization were distributed among twenty different leading banks and consulting firms.

In more recent months it is becoming clear that these organizations are forming the core of a relatively stable set of participants involved in an ongoing relationship with the Agency. In assigning tenders (and even in selecting enterprises to be restructured) in subsequent privatizations, the SPA is working closely with the international partners with whom it has had positive experiences in the first round. Invitations are not entirely open; in some cases the Agency approaches only a few international firms to sound them out about plans for this or that enterprise. And, although we have no documentary evidence, we should not rule out the possibility that effective decisions are being made before the announcement of a competitive bidding for the rights to manage a particular restructuring. When making contracts in these cases, both sides are calculating not simply in terms of the immediate contract at issue but in terms of past performance and in anticipation of future exchanges. Our purpose here is not to denounce a too cozy relationship between the Property Agency and the communities of international banking and consulting. On the contrary, these practices have an economic rationale: relational contracting provides a mechanism in which both parties can gain more information than through more restricted market transactions. On the side of the SPA, such relational contracting lowers transaction costs (for example, the administrative costs of handling an overabundance of bids, or the costs in time and resources in working with too many partners) and can yield more extensive and better information (about capital markets, about international investors, about the marketing and production strategies of foreign companies, and the like) than might be obtained when contracts are made through open competition on a strictly case-by-case basis. ${ }^{46}$

46. To the legitimate objection that such an arrangement should be designated as a "market" because it bears strong resemblance to the organization of some capital markets in developed economies, we have three replies. First, see below on the continuing nature of these con- 
We would seriously fail to understand the process of privatization in Hungary, however, if we focused our attention too narrowly on the State Property Agency-for although the SPA has the legal authority to supervise privatization, the predominant processes restructuring the ownership rights of the large public enterprises is not taking place at its initiative. Instead, the prevalent form of transformation in Hungary should be characterized as the decentralized reorganization of property. Simplifying from a more complicated web of transactions and a wider network of connections, the basic course of such reorganization can be outlined as follows: Under the pressure of enormous debt, declining sales, and threats of bankruptcy or (in the cases of more prosperous enterprises) to forestall takeovers or to attempt to increase autonomy from state ministries, directors of many large public enterprises are taking advantage of several important pieces of legislation that allow state enterprises to establish joint stock companies (RTs) and limited liability companies (KFTs). To be clear, in the typical cases of such reorganizations the state enterprise is not itself transformed into a joint stock enterprise; rather, the managers of the enterprise are breaking up the organization (along divisional, factory, departmental, or even workshop lines) into numerous corporations. ${ }^{47}$ As newly incorporated entities with legal identities, these new units are nominally independent-registered separately, with their own boards of directors and separate balance sheets. The more interesting question is, of course, who owns the shares of these new units? An examination of the computerized records of the Budapest Court of Registry indicates that the controlling shares (in overwhelming proportions) of the corporate satellites launched around the large public enterprises are held by the state enterprises themselves. ${ }^{48}$ For this reason, I prefer to use the term VKFT (in Hungarian, vállalati-KFT, or enter-

tracts. Second, the observation might lead some researchers to further explore features of "relational contracting" in such capital markets in Western economies. (Such research is already ongoing. See, for example, the extraordinary analysis of networks in investment banking by Joel Podolny, Ph.D. dissertation, Department of Sociology, Harvard University, 1991.) Third, for the purposes of our typology, this institutional arrangement (so prevalent in the Hungarian case) deserves some distinctive terminology to set it apart from the use of spot markets (auctions) in the Czech case.

47. Such a restructuring would require preparation of a comprehensive transformation program, under the guidelines of the 1989 Law on Transformation, with the direct involvement of the State Property Agency.

48. I am grateful to László Neumann and Éva Voszka for providing me with these data. 
prise limited liability company) to denote their semi-autonomous organizational status and to indicate their continuity with an organizational innovation of internal subcontracting (the VGMK) that had appeared in the earlier stage of transition. ${ }^{49}$

Property shares in these satellite organizations are not limited, however, to the founding enterprise. The typical cases involve patterns of more mixed ownership. Top and mid-level managers, professional and other staff, and (more rarely) highly skilled workers can be found on the lists of founding partners. But their shares are not large and should not be taken as evidence of "managerial buyouts." More important than private persons is the participation in share ownership in a given corporate unit by other joint stock companies and limited liability companiessometimes by other VKFTs in a similar orbit around the same enterprise, more frequently by joint stock companies or VKFTs spinning around some other enterprise with lines of purchase or supply to the corporate unit. ${ }^{50}$ Most important among the outside owners are banks. In many cases, the establishment of VKFTs and other corporate forms is triggered by enterprise debt, and in the reorganization the creditors, whether commercial banks (whose shares as joint stock companies are still predominantly state-owned) or other credit institutions (also state-owned), exchange debt for equity.

What then is the fastest growing new ownership form in the Hungar-

49. The term VKFT is not my invention but comes from workers I interviewed (in collaboration with János Lukács) in January 1990 during field work in several Hungarian factories. With that acronym these workers were alluding to an earlier hybrid organizational form, the VGMK (enterprise work partnership), involved in a primarily internal system of subcontracting. Although they were free to make contracts and had significant autonomy in organizing production and allocating their "entrepreneurial fees," in the VGMK form the ownership of fixed assets remained in the hands of the parent enterprise. With the term VKFT these workers were denoting the semi-autonomous character of the new limited liability companies spinning around the enterprise. On the VGMK as a hybrid organizational form and precursor of new mixed property forms see, David Stark, "Coexisting Organizational Forms in Hungary's Emerging Mixed Economy," in Victor Nee and David Stark, eds., Remaking the Economic Institutions of Socialism: China and Eastern Europe (Stanford, 1989). For an application of the concept of hybrid property forms to the Chinese economy, see Victor Nee, "Organizational Dynamics of Market Transition: Hybrid Forms, Property Rights, and Mixed Economy in China," Administrative Quarterly, 37:1 (March 1992).

50. See especially the important study by Éva Voszka, Tulajdon—reform (Property-reform) (Budapest, 1991), and also her "From Twilight to Twilight." (Paper presented at the Congress of Hungarian Sociology, Budapest, June 1991.) For an excellent case studies of such reorganization, see Éva Voszka, "Rope Walking: Ganz Danubius Ship and Crane Factory Transformed into a Company," Acta Oeconomica 43: 1-2 (1990), pp. 285-302; see also Mária Móro, "Az állami vállalatok (ál)privatizációja" (Pseudo privatization of state enterprises) Közgazdasági Szemle 38: 6 (1990), pp. 565-584. 
ian economy? ${ }^{51}$ The terminology is cumbersome but it reflects the complex, institutionally intertwined, character of property transformation in Hungary: a limited liability owned by other limited liability companies owned by joint stock companies, banks, and large public enterprises owned by the state.

Has the decentralized reorganization of property rights taken place beyond the control and outside the purview of the governmental agents responsible for privatization? Consistent with its campaign rhetoric in the elections for Parliament, the new Hungarian government, upon taking office in May 1990, adopted a deliberate strategy that promised to slow down privatization and to provide for its centralized management. ${ }^{52}$ But within months, the State Property Agency seems to have realized that it has neither the capacity nor the ability to oversee the privatization of thousands of state enterprises directly. Toleration (bordering on encouragement) of decentralized reorganization appears to be its current posture. This statement should not imply that the Property Agency is unaware of the particular character of these reorganizations. Each corporate spinoff of the kind described above involving assets valued above thirty million forints (approximately $\$ 400,000$ ) or a series of such spinoffs that represents in the aggregate more than fifty percent of the assets of the state enterprise must be approved by the Agency. Although not virtually automatic, the approval rate of such proposals is extraordinarily high. ${ }^{53}$ This high rate of approval suggests that negotiations with the Property Agency precede the submission of a proposal for reorganization. Moreover, case studies and summary reports of corporate reorganizations indicate that the dominant modality of asset evaluation in these cases is unquestionably "bargaining." 54 Whether at the

51. In the past eighteen months the creation of new economic units has increased by two-andone-half times, but the number of corporations has grown by seventeen times (Voszka, "Rope Walking). If we preferred to measure by capitalization instead of counting units, the new semi-autonomous corporate forms would be even more preponderant.

52. In this phase, as Éva Voszka succinctly describes, on issues of privatization the government was much more preoccupied with the question of who should be the seller rather than who should be the new owner. Voszka, "Rope Walking."

53. After consulting with the leading Hungarian experts in this field, our best estimates are that only about ten percent of such proposals are rejected at the level of the SPA. According to the best available data, the official rate of approval of corporate reorganization is seventy percent. But most practitioners in the field acknowledge that many rejected proposals are approved after minor technical changes (or, on occasion, with no revision).

54. Voszka, "Rope Walking", Móro, "Pseudo privatization" and László Neumann, "Labour Conflicts of Privatization in Hungary," Institute for Labour Studies, Budapest, 1991. 
level between the state enterprise and its affiliated corporations or between the enterprise and the state agency, actors exploit every available means of bargaining power.

In which direction will corporate reorganization evolve? Any answer would be premature but the alternatives can be clearly stated. In the first scenario, the current ambiguities in the distribution of property rights will be clarified in favor of the managers of these enterprises. That is, decentralized reorganization will lead to a further concentration of managerial control. ${ }^{55}$ In the second scenario, decentralized reorganization sets the stage for a later round of genuine privatization. That is, although senior management might have broken up enterprises with the aim of buffering the firm from inevitable bankruptcies or increasing their autonomy from state authorities, the establishment of even semiindependent corporate forms might create inviting opportunities for take-over by foreign firms or indigenous private entrepreneurs with limited means to acquire properties when they were more closely bound within the large state enterprises. ${ }^{56}$ In the third scenario, decentralized reorganization is but the first phase of a reconsolidation of state ownership. ${ }^{57}$ This outcome might be only seemingly paradoxical. State elites may be willing to tolerate corporate reorganization (even on a widescale and together with some genuine privatization of the smaller

55. This first scenario envisages a further extension of patterns of institutional cross-ownership and suggests a research agenda to investigate patterns of interlocking directorates in the Hungarian economy.

56. In this scenario, the debt for equity exchange so prevalent in the first round of reorganization could play an important part in the second. The overwhelming problem of enterprise debt (owed to banks, as well as in the disguised form of inter-enterprise debt as firms increasingly delay paying their suppliers in the state sector) is resulting in problems of solvency in the banking sector. There are recent indications that at least some banks are beginning to act like owners-demanding dividends from the KFTs and RTs affiliated with the state enterprises. Where profits are low to non-existent, some state enterprises may be forced to sell some of their affiliated units to pay such dividends. But the prospects for privatizing these units to domestic entrepreneurs are far from encouraging. From where will they receive the capital to make such investments? The same financial crisis that triggers the sales also places restrictions on credit.

57. In such a scenario, the relationship between enterprises and the state would take the form of bargaining and would reflect the continuity of ambiguous property relations in Hungarian state enterprises from the 1968 reforms to the present. But there would be discontinuities as well: in place of the earlier "plan bargaining" and the later "regulatory bargaining," under decentralized reorganization and reconsolidation of state ownership the new relationship would be characterized as dividend bargaining. For a discussion of the continuities and discontinuities in these bargaining relations, see Erzsébet Szalai, “A hatalom metamorfózia?" (Metamorphosis of power?) Valóság 6 (1991), pp. 1-26. 
units ${ }^{58}$ ) provided that the controlling shares remain in institutional hands over which the state can continue to exercise control. 59

Whatever the outcome, we can observe in the meantime that the predominant form of the transformation of property relations in Hungary is the outcome of bargaining about asset evaluation and takes the form of institutional cross-ownership in which enterprise managers use their resources as office-holders to extend their effective exercise of property rights. For these reasons, Hungary exemplifies that cell in our typology representing the intersection of bargaining, corporate owners, and positional resources.

\section{Paths of Extrication and Patterns of Transformation}

The typology of privatization strategies and the discussion of the country cases presented above was to provide a preliminary analytic framework that nirghtt stimulate more systematic comparisons of these cases. The eventual outcome of these strategies will be shaped by the continued tug and pull of politics and the interaction of the state and various social groups in these societies. But whatever these outcomes, it is not too early to observe that the privatization strategies in East Central Europe are beginning from four quite distinctive starting points.

How can we explain these differences? In my view, an explanation of these distinctive strategies of privatization must begin by taking into account their distinctive paths of extrication from state socialismreunification in Germany, capitulation in Czechoslovakia, compromise in Poland, and electoral competition in Hungary. ${ }^{60}$ These diverse paths of extrication, and the preceeding differences in social structure and

58. Encouraging, but limiting, such privatization would be consistent with a policy choice that sought to rationalize the state's ownership role (trimming down the size of its assets) while consolidating its ability to intervene in the economy as an (indirect) owner.

59. In this case, as in all the scenarios, the question of who controls the banks is of fundamental importance. The dismissal in June 1991 of three bank presidents following a sharp dispute over the banks dividend policies indicates that the state is attempting to use it authority in appointing senior banking officials to control the shares in state enterprises held by the banks. It remains to be seen how the state's influence over banks will be changed by the new banking law that took effect on December 1, 1991. Under that legislation, only banks or other financial institutions may hold more than 25 percent of the shares of a bank. The state has until 1995 to reduce its direct ownership of shares in commercial banks.

60. For an elaboration of these concepts, see László Bruszt and David Stark, "Remaking the Political Field in Hungary: From the Politics of Confrontation to the Politics of Competition," in Ivo Banac, ed. Eastern Europe in Revolution (Ithaca, 1992), pp. 13-55. 
political organization that brought them about, have had the consequence that the current political institutions and forms of interest intermediation between state and society differ significantly across our four cases. The collapse of communism in East Germany resulted in the colonization of its new political institutions during incorporation into the powerful state of the German Federal Republic. The capitulation of Communist authorities in Czechoslovakia after decades of suppressing almost all institutions of civil society resulted in the rapid restructuring of its political institutions with relatively few remnants remaining from the earlier period. ${ }^{61}$ Communism did not collapse in Hungary and Poland; its demise was negotiated in both countries. Faced with a powerful, indeed mono-organizational, opposition with deep roots in society, Poland's Communists attempted a compromise solution. And the legacies of this path of extrication, with its institutional guarantees for Jaruzelski and company, remain even today in the still-compromised parliament and a strong presidency together with a nation-wide, though weakening, workers' movement. Hungary's reform Communists, by contrast, attempted to salvage some of their power by entering into direct electoral competition with a seemingly weak political opposition. That political opposition, of course, is now in the government and the Parliament, but the legacy of Hungary's peculiar path remains. In the nearly two years since its roundtable negotiations, Hungary has seen the rapid flourishing of political parties without roots in society, its weak labor movement become further fragmented, and its enterprise managers (as the best-organized social group during the previous decade) become the most powerful social actor in the society.

Thus, it is the relationship between different types of democracy and different types of capitalism, rather than the abstractions of democracy and capitalism, that holds the clue to explaining differences in contemporary Eastern Europe. ${ }^{62}$ The diverse paths of extrication from state

61. Czechoslovakia's current trade unions, for example, bear relatively little resemblance to the pre-1989 unions - in contrast to Hungary where the old official union remains the largest (if tired) trade union federation and to Poland where both Solidarity and the OPZZ are the continued legacy of the 1980s. See Bruszt, "Transformative Politics".

62. Bruszt, "Transformative Politics." On the concepts of different types of capitalism and different types of democracy see the insightful work of Phillipe Schmitter, "Modes of Sectoral Governance: A Typology," unpublished manuscript, Stanford University; and Terry Karl and Phillippe Schmitter, "Modes of Transition in Latin America, Southern and Eastern Europe," International Social Science Journal 128 (March 1991), pp. 269-284. 
socialism yield distinctive patterns across a triangle formed by the state, the market, and the society. It is in terms of these patterns, all too briefly, that we conclude our discussion of privatization strategies in East Central Europe.

With their political incorporation into the German Federal Republic, the citizens of the former East German territories found their futures charted by a political leadership with a strong commitment to thorough marketization. But together with an abiding confidence in the market, this political leadership has profound confidence in the state. This trust, moreover, is accompanied by a deep, and almost indiscriminate, distrust of East German society. Forty years of communism, according to the German leadership, have produced a terrible human tragedy - the personality structures, habits, dispositions, expectations, and mentalities of the citizens of the new lands make them unfit and incapable of managing their affairs. It is not their fault, but they are no longer trustworthy. They must be remolded and reeducated not simply in industrial skills but with new mentalities. Those too old or too thoroughly spoiled by old habits and inclinations must be prevented from obstructing the new course; in the yet undamaged youth of the Eastern lands lies good fortune. ${ }^{63}$ It follows that the German leadership will use the state to transform the economy and reconstruct the society.

The Czechoslovak leaders also have profound confidence in the market. Unlike the Germans, they lack a strong state; yet unlike the Poles, they are not faced with deeply rooted institutions in civil society that might negate their leadership. From this it follows that the Czechoslovak political leadership is pursuing a course of attempting to use the market to transform the economy. So deep is their confidence in the market that they will use it to privatize the economy. Citizen vouchers in Czechoslovakia are not an ideological means to win support through some extra-economic means but are instead the institutional vehicle to achieve the directly economic goals that will provide the basis for short-

63. The reader who suspects exaggeration here would benefit from reading, for example, Werner Gumpel's "The Mentality Problem in the Transition Process from Centrally Planned Economy to Market Economy." (Paper presented at the Conference on Transforming Economic Systems in East-Central Europe, Munich, June 1991.) I have paraphrased Professor Gumpel in the passage above. To quote him directly: "These people must be made to unlearn most of what they were brought up with." 
term and longer-term social support. It would be entirely misleading, therefore, to interpret the Czechoslovak leadership's use of a civic principle as an indication of their deep and abiding commitment to equality. In fact, if they do indeed proceed with the auctioning of the assets of the large public enterprises at the pace and scope being proposed, that scheme is likely to give rise to a relatively rapid differentiation of wealth-because some individuals (not without certain risk, of course) will be able to acquire properties at truly bargain basement prices.

Hungary, by contrast, is in many ways the opposite of the Czechoslovak case. There we find a state elite that is profoundly ambivalent about the market, so much so, that we can say that it distrusts the market. But at the same time, this is a state elite that is highly uncertain about society's trust in its leadership. The current government was popularly and legitimately elected. It enjoys legitimacy but that legitimacy does not convey confidence that the burdens that will necessarily accompany marketization will be accepted by the population. Nor could the likely replacement government formed from parties of the same political elite anticipate greater confidence. Lacking intermediary institutions (such as strong and cohesive trade unions) with whom it could publicly negotiate, that elite has very few means to know where the limits of society's tolerance might be. Thus, it avoids taking decisive steps in fear of society's reaction. And all the while, it engages in a cyclical process of here tightening, there loosening the reins on the galloping enterprise managers.

If the German state leadership trusts the state to remake the society, the Czechoslovaks trust the market to remake the economy, and the current Hungarian leadership distrusts the market while being distrusted by the society, Poland is that case where to keep the trust of society the state must win society's faith in the market. Like the Czechoslovak voucher program, the Polish citizenship vouchers are intended to perform an economic function of promoting privatization where domestic savings are too little to cover the value of the assets. But unlike the Czechoslovak program, the Polish strategy of appealing to the civic principle is not simply auxiliary to, or instrumental for, an economic logic. Whereas in Czechoslovakia the voucher system is a means of achieving a market that is seen as self-legitimating, in Poland, the citizen voucher system is a means of legitimating the market. 


\section{Conclusion: A Market Economy or Modern Capitalism?}

These programs will inevitably be modified as the work of the transformers is transformed by the societies of East Central Europe. The resulting process will resemble innovative adaptations that combine seemingly discrepant elements, bricolage, more than architectural design. We should not be surprised, however, if the blueprints of foreign experts continue to figure in the transformative process. Although the grand designs of cookbook capitalism will not be utilized faithfully as guidelines for action, they will, nonetheless, be useful resources. This hypothesis stems from a view of contemporary East Central European politicians and policy makers as located between their populations who must bear the transition costs, on one side, and, on the other, international agencies and foreign governments that are the potential providers of capital, aid, and access to Western markets.

Master blueprints are not substitutes for stabilization measures, but which East European finance minister would dare enter into negotiations with international lending institutions (the World Bank, the IMF, the European Bank for Reconstruction and Development, and the like) without one? With the diffusion of grand models from one economy to the next we should expect, however, that formulas for external legitimation will be "decoupled" from actual practices. ${ }^{64}$ At the same time, we should note the possibility that politicians might present their own policy preferences as mandated by international agencies. ("The IMF made me do it.") The question of who is legitimating what and by which means is much more complicated than a matter of powerful international agencies dictating to East European politicans who have no choice but compliance.

Will this bricolage result in market economies? Definitive prognosis is, of course, premature. But functioning markets are more likely to

64. The rapidity with which some packages of innovation have become institutionalized (that is, come to be taken for granted) has been extraordinary. No one was shocked, for example, when Yeltsin announced shock therapy for the Russian economy. On diffusion across national boundaries, see David Strang and John W. Meyer, "Institutional Conditions for Diffusion," (Paper presented at the Workshop on New Institutional Theory, Department of Sociology, Cornell University, November 1991.) On the decoupling of formal structures celebrating institutionalized myths from actual organizational practices, see especially John W. Meyer and Brian Rowan, "Institutionalized Organizations: Formal Structue as Myth and Ceremony," in Walter W. Powell and Paul J. DiMaggio, eds, The New Institutionalism in Organizational Analysis (Chicago, 1991), pp. 41-62. 
come from trials and errors that can be corrected, and new opportunities are more likely to be perceived and exploited when transformative processes are decentralized than by grand experiments that are centrally imposed on society.

The more important question is whether the most far-reaching marketization of all aspects of economic life should be the policy goal in contemporary East Central Europe. Advocates of such a goal suffer from two analytic shortcomings: (1) they mistake one possible means as the end itself and (2) they operate in a theoretical universe in which the dichotomies of state or market exhaust the range of viable coordinating mechanisms in modern economies. But (to take the first point) surely the goal of marketization has been, among other ends, to modernize the production processes and improve the international competitiveness of these damaged economies. Yet (moving to the second point), as various currents of thinking in political economy recently indicate, there are sectors in which the most competitive forms of economic coordination are neither market nor statist but new forms whose alternative operations we are only beginning to understand and identify (with such preliminary labels as "networks," "alliances," "inter-firm agreements," and the like). ${ }^{65}$ An exclusive policy of all-encompassing marketization across all sectors would therefore pose a new obstacle and not a means to international competitiveness.

Such a tragedy is likely so long as the policy debate in the transitions from state socialism is dominated by those who mistake the triumph of capitalism as the triumph of the market and look only to the "market revolutions" of Reagan and Thatcher when the real victories went to the industrial reorganizations in Germany and Japan that were neither market nor hierarchical. But modern capitalist economies should not be reduced to only one of their constitutive parts: markets are but one of a

65. See especially the research presented in Rogers Hollingsworth, Philippe Schmitter, and Wolfgang Streeck, eds, Comparing Capitalist Economies: Variations in the Governance of Industrial Sectors (New York, 1992); Schmitter, "Modes"; Robert Boyer, "The Transformations of Modern Capitalism in Light of the Regulation Approach and other Theories of Political Economy." (Paper presented at the Conference on Comparative Governance of Economic Sectors, Bellagio, June 1989.); and Walter Powell, "Neither Market nor Hierarchy: Network Forms of Organization," in B. Staw and L.L. Cummings, eds., Research in Organizational Behavior (Greenwich, Conn., 1990), pp. 295-336. The key analytic move in this new literature is to shift from the preoccupation with micro- or macro-phenomena to a meso-level focus on sectors. These studies suggest an exciting agenda for similar meso-analysis of sectors and localities in contemporary Eastern Europe. 
multiplicity of coexisting coordinating mechanisms in modern capitalism. ${ }^{66}$ Transformative schemes that rely on an exclusive coordinating mechanism do not so much emulate existing capitalism as echo the implementation of state socialism and, like it, carry the danger of sacrificing dynamic efficiency and flexibility that depend on diversity of organizational forms. ${ }^{67}$

66. On the multiple meanings of the term "market," see the excellent paper by Robert Boyer, "Markets within Alternative Coordinating Mechanisms: History, Theory, and Policy in the Light of the Nineties."(Paper presented at the Conference on the Comparative Governance of Sectors, Bigorio, Switzerland, April 1991.)

67. Michael T. Hannan and John Freeman, Organizational Ecology (Cambridge, Mass., 1989), esp. p. 3; and David Stark, "Coexisting Organizational Forms" esp. p. 168. 